\title{
Lymphatic vessels: new targets for the treatment of inflammatory diseases
}

\section{Journal Article}

\section{Author(s):}

Dieterich, Lothar C.; Seidel, Catharina D.; Detmar, Michael

Publication date:

2014-04

Permanent link:

https://doi.org/10.3929/ethz-b-000074032

Rights / license:

In Copyright - Non-Commercial Use Permitted

Originally published in:

Angiogenesis 17(2), https://doi.org/10.1007/s10456-013-9406-1 


\title{
Lymphatic vessels: new targets for the treatment of inflammatory diseases
}

\author{
Lothar C. Dieterich • Catharina D. Seidel • \\ Michael Detmar
}

Received: 28 August 2013/Accepted: 30 October 2013/Published online: 9 November 2013

(C) Springer Science+Business Media Dordrecht 2013

\begin{abstract}
The lymphatic system plays an important role in the physiological control of the tissue fluid balance and in the initiation of immune responses. Recent studies have shown that lymphangiogenesis, the growth of new lymphatic vessels and/or the expansion of existing lymphatic vessels, is a characteristic feature of acute inflammatory reactions and of chronic inflammatory diseases. In these conditions, lymphatic vessel expansion occurs at the tissue level but also within the draining lymph nodes. Surprisingly, activation of lymphatic vessel function by delivery of vascular endothelial growth factor-C exerts antiinflammatory effects in several models of cutaneous and joint inflammation. These effects are likely mediated by enhanced drainage of extravasated fluid and inflammatory cells, but also by lymphatic vessel-mediated modulation of immune responses. Although some of the underlying mechanisms are just beginning to be identified, lymphatic vessels have emerged as important targets for the development of new therapeutic strategies to treat inflammatory conditions. In this context, it is of great interest that some of the currently used anti-inflammatory drugs also potently activate lymphatic vessels.
\end{abstract}

Keywords Lymphangiogenesis · Inflammation ·

Psoriasis · Arthritis · Endothelial cells

Lothar C. Dieterich and Catharina D. Seidel have contributed equally to this work.

L. C. Dieterich · C. D. Seidel · M. Detmar ( $\square)$

Institute of Pharmaceutical Sciences, Swiss Federal Institute of

Technology (ETH) Zurich, Wolfgang-Pauli-Strasse 10, HCI H

303, 8093 Zurich, Switzerland

e-mail: michael.detmar@pharma.ethz.ch

\section{Introduction}

The lymphatic system is closely connected to inflammatory processes and immune functions. One of its major functions is the transport of immune cells and soluble antigens from the periphery to the lymph nodes, which are the primary sites for activation of immune responses. Correspondingly, lymphatic vessels can be found in most organs and their network is particularly dense in the skin and near mucosal surfaces, the main entry sites for foreign material and pathogens into the body [1, 2]. It is thus surprising that lymphatic vessels have been thought for decades to merely represent a passive drainage system without any active role in disease processes. However, recent findings indicate that lymphatic vessels are dynamic structures that sensibly react to inflammatory stimuli and that are activated, both at the level of the peripheral inflamed tissue and within the draining lymph nodes. In this review, we highlight the capacity of lymphatic vessels to regulate inflammation resolution and to modulate immune responses and tolerance, with a focus on therapeutic approaches to target lymphatic vessels for the treatment of inflammatory conditions.

\section{Molecular markers of lymphatic endothelium and their modulation in inflammation}

The dramatic progress in our understanding of the active role of lymphatic vessels in development, physiology and disease is due to the identification of lymphatic endothelial cell (LEC)-specific markers [3], in particular vascular endothelial growth factor receptor (VEGFR)-3, Prox1, LYVE-1 and podoplanin. These LEC markers allow for the specific staining of LECs in tissue sections, their specific 
isolation in vitro and ex vivo and, subsequently, the characterization of differentially expressed genes and proteins in LECs versus blood vascular endothelial cells (BECs) [4-7].

VEGFR-3 is a receptor tyrosine kinase for the lymphangiogenic growth factors VEGF-C and -D and is crucial for growth, survival and migration of LECs $[8,9]$. During embryonic development, VEGFR-3 is expressed on both blood vessels and on lymphatic vessels (LVs), whereas it is mostly expressed by LECs in healthy adult tissue [10]. Some VEGFR-3 expression has been found on blood capillaries in the spleen, kidney, and glands of the endocrine system [11]. Prox 1 is required for the development of the lymphatic system [12] and plays a major role as master transcription factor responsible for LEC differentiationectopic Prox 1 expression partially reprograms cultured BECs to a LEC-like phenotype [7, 13]. LYVE-1, a homolog of the CD44 glycoprotein, is a hyaluronan receptor of yet unclarified function that is predominantly expressed by LECs in adult tissues [14, 15]. LYVE-1 expression is high in lymphatic capillaries but very low in collecting LVs [16]. LYVE-1 is only rarely seen on blood vessels, such as sinusoidal endothelial [14, 17]. Podoplanin is a membrane glycoprotein that is expressed by LECs but not BECs [18] and that plays a major role in normal lymphatic development [19]. While its expression is high on LECs of lymphatic capillaries, some LECs in lymphatic pre-collectors show low podoplanin expression [20].

Although these markers allow the distinction of LECs from BECs in most tissues, some non-endothelial expression has been observed. For instance, VEGFR-3 has been found to be expressed by corneal DCs [21] and epithelium [22], and Prox1 is expressed in liver, pancreas [23] and the brain [24, 25]. Moreover, strong LYVE-1 expression has been observed on a subset of macrophages in various tissues, which makes it essential to distinguish them from LVs on tissue sections [26-28]. Podoplanin is also expressed in the choroid plexus of the brain [29, 30], alveolar type I epithelial cells in the lung [29, 31], ciliary epithelia of the intestine [29], stromal cells of lymphoid organs such as the spleen [32] and LNs [33], possibly leukocyte subsets including macrophages [34, 35] and Th17 cells [36], nerve fibers and bile duct associated mesenchymal cells in the liver [37]. Therefore, it is recommended to use combinations of two different lymphatic markers or a combination of a lymphatic marker with a pan-endothelial marker such as CD31 [38] for the unambiguous detection of lymphatic vessels.

Despite their usefulness for the identification of lymphatic vessels in normal tissues, the expression of these lymphatic markers can be strongly modulated during tumorigenesis [39] and inflammation, and these changes are likely stimulus- and species-specific. In general, the expression of most LEC markers appears to be down-regulated on lymphatic vessels during inflammation, whereas upregulation of LEC markers by inflammatory stimuli has been observed in BECs, at least under culture conditions [40]. Importantly, LYVE-1 was found to be down-regulated on LECs during chronic airway inflammation in vivo [41] and also on cultured LECs upon inflammatory stimuli [42]. Lower mRNA levels of VEGFR-3, LYVE-1 and Prox 1 and reduced podoplanin protein expression were found on cutaneous LECs during contact hypersensitivityinduced inflammation in mice but not by complete Freund's adjuvant-induced inflammation [43]. Our own studies in acute skin inflammation models recently also revealed inflammation-mediated down-regulation of VEGFR-3 on LECs [44] whereas up-regulation of VEGFR3 and Prox- 1 on LECs was found in a peritonitis model, possibly mediated by nuclear factor-kappaB activation [45]. Together, these studies highlight the stimulusdependent response of LECs with regard to marker expression, and they indicate that at least two different LEC markers should be used to investigate the response of lymphatic vessels in inflammation.

\section{Lymphatic vessels expansion in inflammation}

Expansion of the lymphatic vascular network has been observed in several inflammatory conditions, both in experimental mouse models and in human inflammatory diseases (reviewed in [46]). This expansion includes dilation of pre-existing vessels (lymphatic hyperplasia) as well as induction of lymphatic sprouting (lymphangiogenesis) and the growth of new lymphatic vessels, resulting in an increased lymphatic vascular density. Our laboratory identified enlargement of lymphatic vessels in the skin of patients suffering from psoriasis, a chronic inflammatory skin disease, as well as in a mouse model of psoriasis [47]. In this model, transgenic mice with skin-specific overexpression of VEGF-A develop a chronic, psoriasis-like skin inflammation after treatment with the contact sensitizer oxazolone, associated with angiogenesis and with lymphatic vessel expansion (Fig. 1 a, b). Similarly, lymphatic expansion has been observed in clinical samples and mouse models of arthritis [48-50], atopic dermatitis [51] and inflammatory bowel disease $[52,53]$.

It is currently a matter of debate whether the inflammation (or growth factor)-induced lymphatic vessel expansion might be reversible or not. After adenoviral delivery of VEGF-A to mouse ears, expanded and functionally impaired lymphatic vessels persisted for many months whereas angiogenic blood vessels regressed [54], and chronic airway inflammation-induced lymphatic hyperplasia persisted for an extended period of time even 

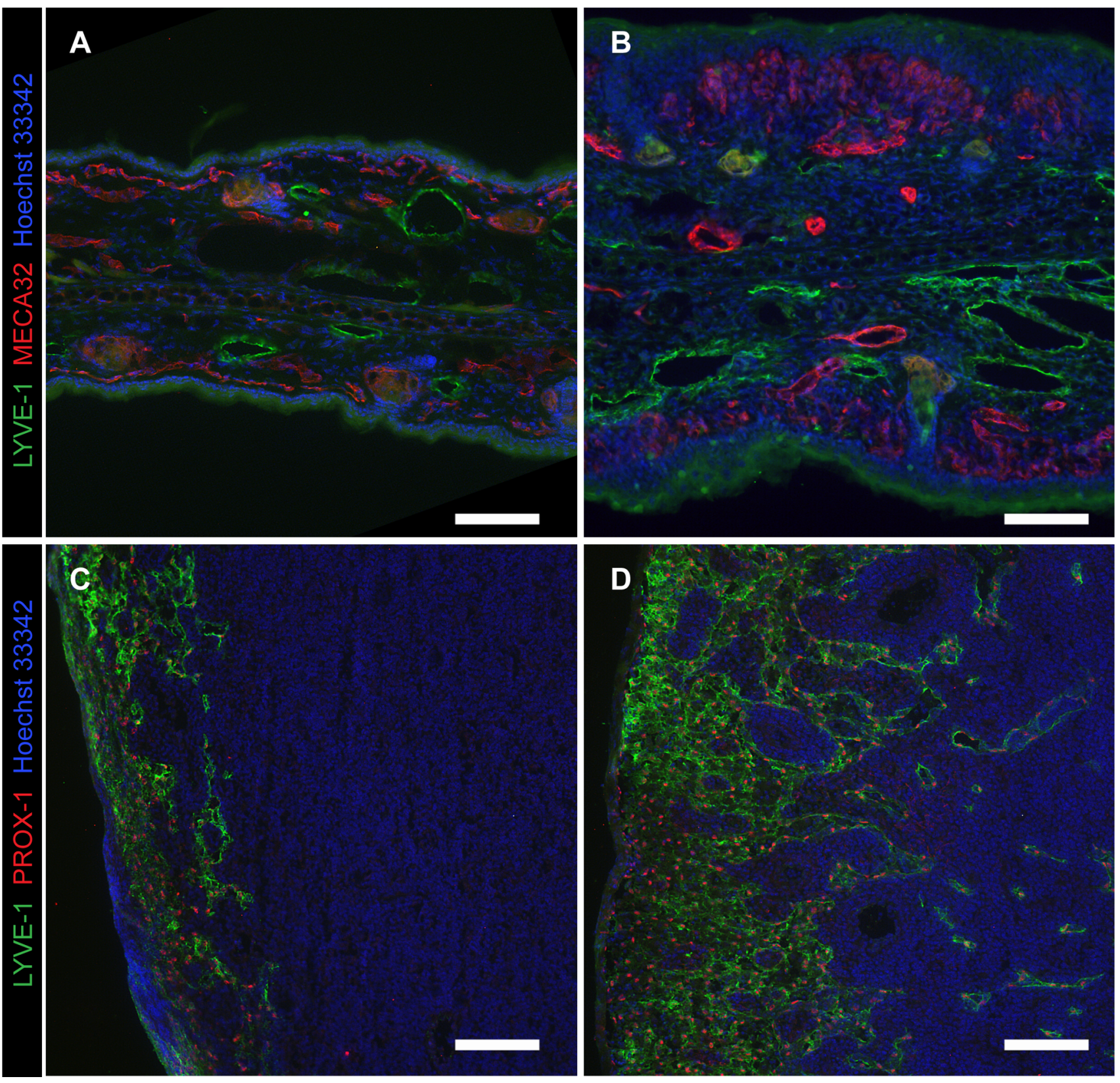

Fig. 1 Microscopic images of LYVE-1+ lymphatic vessels (green) and Meca32-positive blood vessels (red) in healthy mouse ear skin a and in chronically inflamed ear skin of the K14-VEGF-A mouse psoriasis model $\mathbf{b}$. Note the tissue swelling and the enlargement and of lymphatic vessels in inflammation. c Lymphatic vasculature

stained for LYVE-1 (green) and Prox-1 (red) in the auricular lymph node of a healthy mouse. d Expansion of the lymphatic vascular network in the auricular lymph node at day 7 after induction of ear skin inflammation. Nuclei are stained in blue. Bars $=100 \mu \mathrm{m}$. (Color figure online)

after inflammatory resolution [41]. In contrast, inflammation-induced lymphatic expansion regressed after several months in an experimental skin inflammation model [55] and in suture-induced inflammation in the mouse cornea where lymphatic vessels expanded faster, however, upon re-challenge [56]. Clearly, further research is warranted to investigate the dynamics of lymphatic networks expansion in different types of inflammation.

\section{Lymph node lymphangiogenesis}

In 2005, studies from our laboratory revealed that solid tumors can induce lymphangiogenesis within their draining lymph nodes ("lymph node lymphangiogenesis"), even before they actually metastasize to these lymph nodes [57]. Shortly thereafter, it became clear that lymph node (LN) lymphangiogenesis also occurs in those lymph nodes that 


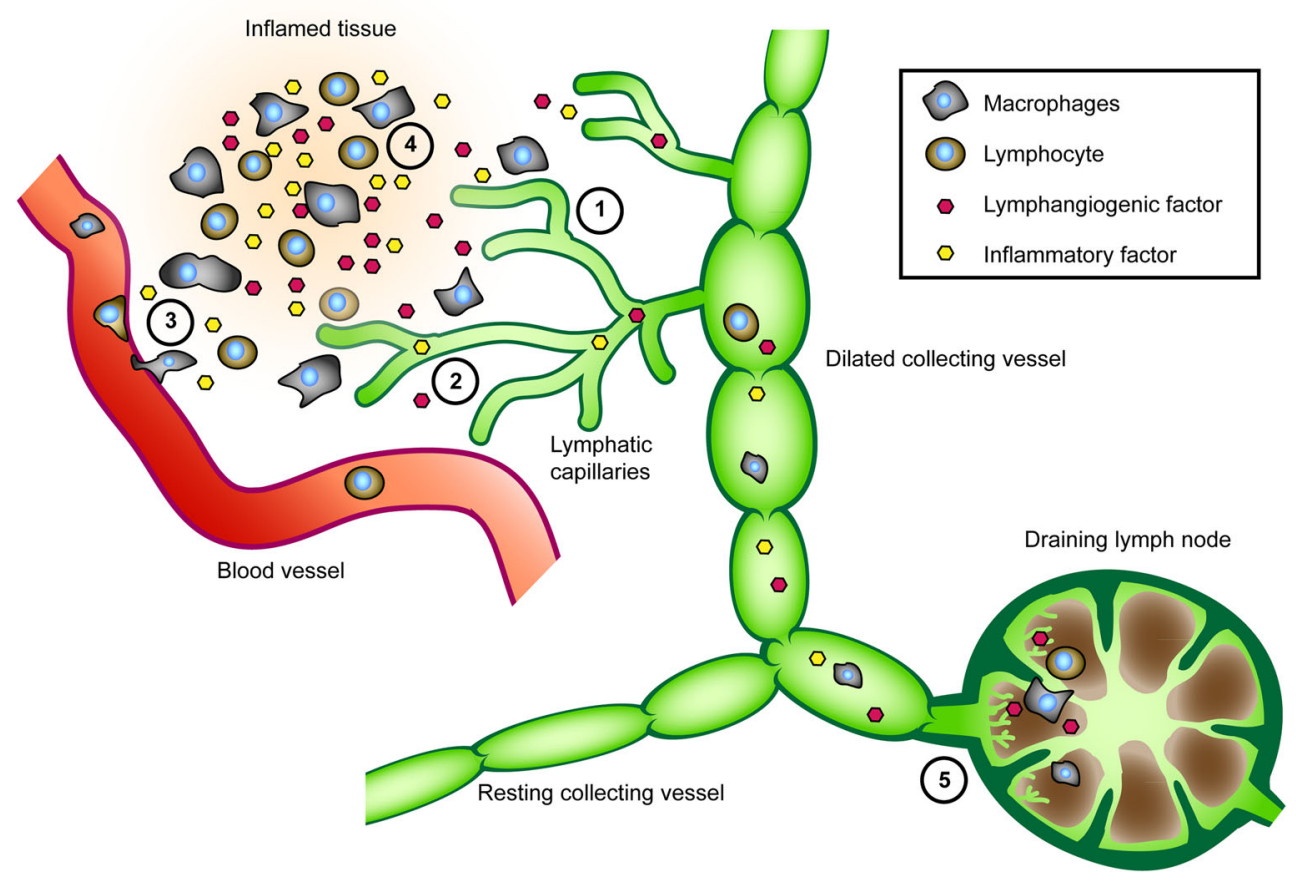

Fig. 2 Schematic overview of the lymphangiogenic process during inflammation. Lymphangiogenic factors produced in the inflamed stroma directly act on local lymphatic vessels and induce sprouting and vessel dilation 1 . Inflammatory factors may directly stimulate lymphatic vessel expansion 2. Inflammatory factors also act on local blood vessels and mediate the recruitment of macrophages which

drain inflammatory sites, in particular inflamed skin [58, 59] (Fig. 1 C, D). This lymphatic expansion may be mediated by VEGF family members and other lymphangiogenic factors released by cells within the $\mathrm{LN}$, such as $\mathrm{B}$ cells [58] or macrophages [60], as well as by factors released at the site of inflammation and subsequently drained to the LN [59]. The relative contribution of locally produced versus peripherally produced mediators towards the expansion of lymphatic vessels within LNs appears to depend on the experimental model. It is of interest that interferon-gamma producing $\mathrm{T}$ lymphocytes have been found to inhibit LN lymphangiogenesis [61] and that inflammatory LN lymphangiogenesis was reversible in a skin inflammation model [55].

\section{Mediators of inflammatory lymphatic vessel expansion}

VEGF-C represents the best characterized inducer of inflammatory lymphangiogenesis, acting via binding to VEGFR-3 and neuropilin-2 [9] and-after proteolytic cleavage- to VEGFR-2 that is also expressed by lymphatic endothelial cells [62]. Whereas the effects of the lymphangiogenic factor VEGF-D in inflammation are at present less well studied, VEGF-A has emerged as a major express lymphangiogenic growth factors such as VEGF-C 3. Inflammatory factors may directly induce transcription of lymphangiogenic factors in immune cells and other stromal cells in the inflamed tissue 4. Lymph node lymphangiogenesis is induced by factors drained from the site of inflammation and also by factors produced locally by lymph node resident cells 5

activator of inflammatory lymphatic vessel expansion within the peripheral inflamed tissue as well as within the draining lymph nodes $[47,54,58,59,62,63]$. These effects are likely mediated both directly, via activation of VEGFR2 on LECs, and indirectly via recruitment of inflammatory cells and activation of VEGF-C production by blood vessels. Macrophages appear to represent the major source of VEGFs in inflammation [60], but other inflammatory and resident cells likely contribute as well [58]. The major stimuli of VEGF production in inflammation are inflammatory mediators and hypoxic tissue conditions [64].

Several other growth factors have been implicated in the mediation of lymphangiogenesis, including angiopoietins 1 and 2 [65, 66], fibroblast growth factors [67, 68], hepatocyte growth factor [69], platelet-derived growth factors [70], and insulin-like growth factors [71]. Their relative contribution to inflammatory lymphatic vessel expansion remains at present unclear (Fig. 2).

There is increasing evidence that macrophages play a major role in lymphangiogenesis in general, and in particular in inflammatory lymphangiogenesis, via secretion of lymphangiogenic factors $[60,72,73]$. Thus, a large number of mediators that recruit macrophages/myeloid-derived cells to inflamed tissues have been implicated in the indirect promotion of lymphatic vessel expansion including IL- 
$1 \beta$ [74, 75], IL-4 [51], and CSF-1 [76]. In addition, inflammatory mediators were found to directly stimulate the production of VEGF-C by resident cells such as synoviocytes [77]. Some inflammatory factors likely stimulate LECs directly. However, due to the pleiotropic nature of these mediators, these effects are difficult to investigate in vivo. Consequently, direct effects of inflammatory factors on lymphangiogenesis have mostly been described in vitro, using proliferation, migration, or tube formation assays with cultured LECs. Such assays cannot reproduce the whole complexity and cellular interactions during inflammatory lymphangiogenesis in vivo, and it is therefore not surprising that results obtained in vitro do not always coincide with observations made in vivo. One example is IL- $1 \beta$, which has been found to stimulate lymphangiogenesis in vivo but to inhibit LEC tube formation in vitro $[74,78]$. A detailed list of inflammatory cytokines and chemokines and their known activities on lymphatic endothelial cells in vitro and lymphangiogenesis in vivo is provided in Table 1.

\section{Lymphatic drainage function in inflammation}

It has been a topic of great dispute whether and how the lymphatic drainage function is affected in acute and chronic inflammatory conditions. Recently developed in vivo imaging techniques and newly developed dyes and tracers have helped to investigate this issue. There is strong evidence that inflammation-draining lymphatic vessels are hyperpermeable and drain less well, as found in a mouse psoriasis model with transgenic VEGF-A overexpression in the skin [47] and after acute or chronic UVB irradiation of the skin [79]. Whereas LPS (lipopolysaccharide)-induced peritonitis was associated with impaired lymphatic drainage in the diaphragm [73], acute skin inflammation induced by LPS was associated with increased lymphatic flow [60]. In the $\mathrm{K} / \mathrm{BxN}$ mouse model of arthritis, which is dependent on a $\mathrm{T}$ cell mediated immune response against an autoantigen, an initial increase in lymphatic flow during the acute phase was followed by an increase in lymphangiogenesis but a decrease in lymphatic flow during the chronic phase [80]. Similarly, in the TNF- $\alpha$ transgenic model, in which arthritis develops independently of a specific immune response, lymphatic drainage from the inflamed paws was reported to be reduced in the chronic disease phase of the disease [81]. However, the same group reported increased drainage from popliteal lymph nodes in the same model [82]. Thus, there is a need for the standardization and quantification of methods applied for measuring lymph flow in vivo.

VEGF-A appears to be a mediator of the lymphatic dysfunction in inflammation. VEGF-A expression is consistently increased in inflammatory dieseases, and adenoviral delivery of VEGF-A to the skin resulted in enlarged, functionally abnormal LVs with delayed lymphatic clearance [54]. K14-VEGF-A transgenic mice, which over-express VEGF-A in the skin, develop a psoriasis-like inflammation with enlarged and leaky LVs [47, 83]. In UVB-irradiation studies, VEGF-A overexpression resulted in increased skin inflammation and lymphatic dysfunction, whereas blockade of VEGF-A signaling prevented UVB-induced LV enlargement and hyperpermeability, edema formation and inflammation [79, 84]. Our own recent studies indicate that lymphatic vessel drainage function might be less affected during acute skin inflammation but becomes severly impaired under chronic inflammatory conditions [44]. Overall, the increased blood vascular permeability in chronically inflamed tissues, often mediated by VEGF-A, appears to be associated with decreased lymphatic fluid drainage, often also mediated by VEGF-A, promoting edema formation and reduced drainage of inflammatory mediators from the infamed site.

\section{Activation of lymphatic vessel function inhibits inflammation}

It has been a matter of debate whether lymphatic vessels contribute to inflammatory processes-via transport of immune cells towards the lymph nodes and secretion of inflammatory chemokines-or whether they might contribute to inflammation resolution-via drainage of inflammatory cells, mediators and fluids away from the inflamed tissue. Our laboratory has recently found that activation of lymphatic vessels via transgenic overexpression of VEGF-C or VEGF-D in the skin leads not only to an expanded lymphatic network with enhanced fluid drainage, but also to a potent inhibition of acute and chronic skin inflammation [44, 63]. In accordance with these findings, viral delivery of VEGF-C increased lymphangiogenesis and lymphatic flow, and also reduced the severity of joint lesions in a model of chronic inflammatory arthritis [81]. Importantly, intradermal injection of the VEGFR-3 specific mutant VEGF-C156S inhibited UVB irradiation-induced lymphatic impairment, edema formation and inflammation in the skin [85], indicating potential therapeutic applications. In agreement with these therapeutic results, blockade of VEGFR-3 resulted in functionally impaired LVs with decreased drainage, enhanced edema, increased inflammatory cell infiltration and prolonged inflammation in models of UVB irradiation-induced skin inflammation, psoriasis, chronic airway inflammation, chronic inflammatory arthritis and bacterial pathogeninduced acute inflammation [41, 60, 63, 82, 86], as well as in prolonged inflammation in experimental inflammatory 
Table 1 Pro-inflammatory factors involved in lymphangiogenesis and lymphatic hyperplasia

\begin{tabular}{|c|c|c|c|c|}
\hline Factor & Model & Effect & Mode of action & References \\
\hline \multicolumn{5}{|l|}{ TLR ligands } \\
\hline LPS & Intraperitoneal/intradermal injection & $\begin{array}{l}\text { Lymphangiogenesis } \\
\qquad(+)\end{array}$ & Recruitment of macrophages & {$[60,72,73]$} \\
\hline \multicolumn{5}{|l|}{ TNF family } \\
\hline \multirow[t]{3}{*}{ TNF- $\alpha$} & Chronic M.pulmonis infection & $\begin{array}{l}\text { Lymphangiogenesis } \\
\qquad(+)\end{array}$ & $\begin{array}{l}\text { Recruitment of inflammatory } \\
\text { cells, induction of VEGF-C }\end{array}$ & {$[115]$} \\
\hline & In vitro stimulation of primary synoviocytes & $\begin{array}{l}\text { Lymphangiogenic } \\
\text { factors }(+)\end{array}$ & $\begin{array}{l}\text { Induction of VEGF-C in } \\
\text { synoviocytes }\end{array}$ & [77] \\
\hline & In vitro LEC tube formation & Tube formation $(-)$ & Direct effect & [78] \\
\hline \multicolumn{5}{|l|}{ Interleukins } \\
\hline \multirow[t]{3}{*}{ IL-1 $\beta$} & IL- $1 \beta$ over-expression in trachea & $\begin{array}{l}\text { Lymphangiogenesis } \\
(+)\end{array}$ & Recruitment of macrophages & [74] \\
\hline & Corneal lymphangiogenesis & $\begin{array}{l}\text { Lymphangiogenesis } \\
(+)\end{array}$ & Recruitment of macrophages & {$[75]$} \\
\hline & In vitro LEC tube formation & Tube formation (-) & Direct effect & [78] \\
\hline IL-4 & IL-4 driven atopic dermatitis & $\begin{array}{l}\text { Lymphangiogenesis } \\
(+)\end{array}$ & Recruitment of macrophages & {$[51]$} \\
\hline \multirow[t]{2}{*}{ IL-6 } & In vitro stimulation of OSCC cells & $\begin{array}{l}\text { Lymphangiogenic } \\
\text { factors }(+)\end{array}$ & $\begin{array}{l}\text { Induction of VEGF-C in OSCC } \\
\text { cells }\end{array}$ & {$[112]$} \\
\hline & In vitro LEC tube formation & Tube formation $(+)$ & Direct effect & [116] \\
\hline \multirow[t]{2}{*}{ IL-17 } & In vitro stimulation of NSCLC cells & $\begin{array}{l}\text { Lymphangiogenic } \\
\text { factors }(+)\end{array}$ & $\begin{array}{l}\text { Induction of VEGF-C in } \\
\text { NSCLC cells }\end{array}$ & [117] \\
\hline & Corneal lymphangiogenesis & $\begin{array}{l}\text { Lymphangiogenesis } \\
(+)\end{array}$ & $\begin{array}{l}\text { Induction of VEGF-C and -D } \\
\text { in the cornea }\end{array}$ & [118] \\
\hline \multicolumn{5}{|c|}{ Colony stimulating factors } \\
\hline CSF-1 (M-CSF) & Tumor lymphangiogenesis & $\begin{array}{l}\text { Lymphangiogenesis } \\
(+)\end{array}$ & Recruitment of macrophages & {$[76]$} \\
\hline CSF-2 (GM-CSF) & In vitro LEC tube formation & Tube formation $(+)$ & Direct effect & [116] \\
\hline \multicolumn{5}{|l|}{ Interferons } \\
\hline \multirow[t]{2}{*}{ INF- $\gamma$} & $\begin{array}{l}\text { LPS/ConA induced skin inflammation } \\
\text { In vitro LEC sprouting and }\end{array}$ & $\begin{array}{l}\text { Lymphangiogenesis } \\
(-) \text { Sprouting }(-)\end{array}$ & Direct effect & {$[61]$} \\
\hline & tube formation & Tube formation (-) & Direct effect & [78] \\
\hline \multicolumn{5}{|l|}{ Chemokines } \\
\hline CCL19 & Diffuse alveolar damage & $\begin{array}{l}\text { Lymphangiogenesis } \\
(+)\end{array}$ & Recruitment of macrophages & [119] \\
\hline \multirow[t]{2}{*}{ CXCL8 (IL-8) } & In vitro LEC tube formation & Tube formation $(+)$ & Direct effect & {$[100]$} \\
\hline & $\begin{array}{l}\text { In vitro LEC tube formation, Matrigel plug } \\
\text { assay, cornea micropocket assay }\end{array}$ & $\begin{array}{l}\text { Lymphangiogenesis, } \\
\text { tube formation }(+)\end{array}$ & Direct effect & {$[101]$} \\
\hline CXCL12 (SDF-1) & $\begin{array}{l}\text { In vitro LEC tube formation, matrigel plug } \\
\text { assay }\end{array}$ & $\begin{array}{l}\text { Lymphangiogenesis, } \\
\text { tube formation }(+)\end{array}$ & Direct effect & {$[120]$} \\
\hline \multicolumn{5}{|l|}{ Other factors } \\
\hline \multirow[t]{2}{*}{$\begin{array}{l}\text { Prostaglandin E2 } \\
\text { (PGE2) }\end{array}$} & $\begin{array}{l}\text { In vitro stimulation of lung adenocarcinoma } \\
\text { cells }\end{array}$ & $\begin{array}{l}\text { Lymphangiogenic } \\
\text { factors }(+)\end{array}$ & $\begin{array}{l}\text { Induction of VEGF-C in lung } \\
\text { adenocarcinoma cells }\end{array}$ & [121] \\
\hline & Matrigel plug assay & $\begin{array}{l}\text { Lymphangiogenesis } \\
\qquad(+)\end{array}$ & Induction of VEGF-C and -D & {$[122]$} \\
\hline \multirow[t]{2}{*}{ Nitric oxide (NO) } & $\begin{array}{l}\text { In vitro LEC tube formation, UVB induced } \\
\text { inflammation }\end{array}$ & $\begin{array}{l}\text { Tube formation }(+) \\
\text { hyperplasia }(+)\end{array}$ & Direct effect & [123] \\
\hline & In vitro LEC proliferation & $\begin{array}{l}\text { Proliferation }(+), \\
\text { hyperplasia }(+)\end{array}$ & Direct effect & {$[124]$} \\
\hline
\end{tabular}

OSCC oral squamous cell carcinoma, NSCLC non-small-cell lung cancer 
bowel disease [87]. Overall, these studies clearly indicate that promotion of lymphatic drainage by an expanded functional lymphatic network might represent a new therapeutic strategy to treat inflammatory diseases.

\section{Modulation of inflammation and immune responses by lymphatic vessels}

In addition to the increased drainage function, activation of lymphatic vessels by VEGF-C and other mediators might also induce additional anti-inflammatory mechanisms [88]. While it is beyond the scope of this review to provide a detailed discussion of the various effects of LECs on the immune system, it is important to note that LECs are not only involved in dendritic cell (DC) and lymphocyte trafficking from the periphery to the lymph nodes, but also in regulating lymphocyte egress from lymph nodes, immune cell maturation and tolerance.

Upon inflammation, the chemokine-scavenging receptor D6, an essential regulator of inflammatory leukocyte interactions with LECs, is up-regulated on LECs. D6 binds all inflammatory CC-chemokines but not homeostatic chemokines such as CCL21, followed by internalization and degradation, which prevents inappropriate adhesion of inflammatory leukocytes and immature DCs to LECs [89]. D6 is also expressed by mucosal LECs where it controls intestinal inflammation [90]. Furthermore, LECs are the sole source of sphingosine-1-phosphate (S1P) in the LN [88], which is essential to release activated lymphocytes from LNs, while egress of naïve lymphocytes is transiently blocked during inflammation [91]. Importantly, during prolonged inflammation, VEGF-A-induced LN lymphangiogenesis was recently found to restore lymphocyte egress from LNs independently of their activation status [92].

LECs may also directly modulate the maturation of immune cells. Recent studies found that LN stromal cell populations, among them LECs, limit DC-induced proliferation of $\mathrm{T}$ cells to control the expansion of activated $\mathrm{T}$ cells within the LN [93, 94]. Moreover, LECs seem to suppress DC maturation and function in inflamed tissue [95]. This suppression was active only in the absence of pathogen-derived signals and might thus provide a relatively unspecific peripheral tolerance mechanism during inflammation.

Diverse LN stromal cell types, among them LECs, can act as antigen presenting cells. They express a characteristic set of peripheral tissue antigens, controlled by an unknown, autoimmune regulator (Aire)-independent mechanism [96]. LN LECs present peripheral tissue antigens on MHC-I, leading to deletion of self-reactive CD8 T cells [96, 97]. This LEC-mediated deletion of self-reactive $\mathrm{T}$ cells requires two interdependent pathways: a lack of costimulation and provision of the inhibitory molecule PDL1. Lack of costimulation leads to an up-regulation of PD1 on CD8 T cells, further enhancing inhibition via the PDL1/PD-1 pathway. Confirming the importance of both pathways, peripheral tissue antigen presentation by LECs together with PD-L1 blockade or exogenous costimulation lead to the development of autoimmune disease [98]. In contrast to DCs, LECs up-regulate the inhibitory molecule PD-L1 upon TLR3 stimulation, suggesting a tolerogenic function of LECs even during exposure to danger signals [97].

\section{Lymphatic vasculature as a new therapeutic target}

Much progress has been made with regard to inhibiting tumor-associated lymphangiogenesis and metastasis by targeting the VEGF-C/VEGF-D/VEGFR-3 axis. The currently evaluated drugs include anti-VEGFR-3 antibodies, anti-VEGF-C or -D antibodies, as well as antibodies against neuropilin-2, and at least one of them, a monoclonal antibody against VEGFR-3 (IMC-3C5, ImClone Systems) has recently entered clinical testing [99]. In contrast, with regard to inflammatory diseases, lymphatic vessel function should most likely be therapeutically enhanced, based on the findings discussed above. While the direct intradermal injection of VEGF-C protein has shown efficacy in preclinical skin inflammation models [63, 85], this approach does not seem feasible for the treatment of human diseases. Similar restrictions might apply to the reported use of viral vectors to deliver VEGF-C [2], cell based therapies [100] and application of interleukin- 8 [101], since sufficient site-specific delivery of these agents represents a major challenge, in addition to safety aspects.

It is of interest, however, that several established antiinflammatory drugs have been recently found to also affect lymphangiogenesis. In particular, all-trans-retinoic acid was identified to play a major role during embryonic lymphatic development, and 9-cis retinoic acid was shown to promote lymphangiogenesis and lymphatic vessel regeneration in vivo [102, 103]. Given the clinical use of retinoids for the treatment of inflammatory diseases such as psoriasis and psoriatic arthritis, one might speculate that their pro-lymphangiogenic activity might contribute to the therapeutic effects in these diseases.

Most non-steroidal antiinflammatory drugs (NSAIDs) inhibit COX-1 and/or COX-2 enzymes which mediate the biosynthesis of prostaglandins including prostaglandin E2. Recently, it was found that prostaglandin E2 promotes lymphangiogenesis by up-regulation of VEGF-C and -D (Table 1) and that COX inhibitors reduce tumor-induced lymphangiogenesis [104] and secondary lymphedema [105]. Moreover, NSAIDs inhibited VEGF-D mediated 
dilation of tumor draining collecting lymphatics [106]. At present, however, more research is needed to investigate how these findings might be related to anti-inflammatory efficacy. Similarly, glucocorticoid treatment reduced lymphangiogenesis in a model of chronic infection with $M$. pulmonis [107], in cornea inflammation [108, 109] and in tumor xenografts [110]. However, glucocorticoids might also have direct activating effects on lymphatic endothelial cells (our own unpublished results), and hydrocortisone is routinely added to cultures of LECs. Therefore, future studies are needed to directly investigate the effects of antiinflammatory drugs on lymphatic vessel function, with a particular focus on fluid drainage and immune cell interactions.

Anakinra, a recombinant version of the endogeneous IL1 scavenger IL-1Ra, and tocilizumab, an IL-6R blocking antibody, have also been found to affect lymphangiogenesis [111, 112]. Both drugs have been approved for the treatment of rheumatoid arthritis but their effects on lymphangiogenesis in inflamed joints need to be investigated. Importantly, the TNF- $\alpha$ neutralizing antibody infliximab has been reported to increase lymphangiogenesis in treated mice suffering from inflammatory arthritis [113]. Since infliximab is also used for other auto-immune diseases such as psoriasis and colitis, it will be of great interest to investigate whether infliximab treatment has similar effects in those conditions as well, and whether the anti-inflammatory activity of infliximab may be at least in part dependent on its pro-lymphangiogenic activity.

\section{Outlook}

The active role of lymphatic vessels in inflammation is well established today and lymphatic vessels have become the target for the development of new therapeutic strategies to treat inflammatory diseases. Thus, we have recently initiated a screening program, using a three-dimensional LEC sprouting assay as a read-out [114], to identify new activators of lymphatic vessel function. Using phenotypic screens of small molecule chemical libraries as well as natural extract libraries, we identified a natural extract and defined molecular compounds that promote lymphatic vessel drainage in vivo (unpublished data). It will be of great interest to investigate whether these compounds might also affect lymphatic vessels under inflammatory conditions. However, there are currently many unanswered questions with regard to the functional role of lymphatic vessels in inflammation. Can we specifically promote certain functions of lymphatic vessels such as fluid drainage or anti-inflammation, without major effects on lymphangiogenesis? Can we promote inflammatory lymphatic vessel pumping and reduce lymphatic hyperpermeability at the same time? Is the expansion of lymphatic vessels within inflamed tissues and their draining lymph nodes reversible in human diseases? What is the detailed functional role of lymph node lymphangiogenesis with regard to inflammation and tolerance? What are the effects of currently used anti-inflammatory drugs on inflammation-associated lymphangiogenesis and/ or lymphatic drainage function? Thus, future studies are needed to better understand the molecular mediators and pathomechanisms regulating lymphatic vessel activation in inflammation.

Acknowledgments We thank Alexandra Ochsenbein for providing tissue sections. Work in the authors' laboratory is supported by the Swiss National Science Foundation, the European Research Council, the ETH Zurich, the Krebsliga Zürich and the Krebsliga Schweiz.

Conflict of interest The authors declare no competing financial interests.

\section{References}

1. Albrecht I, Christofori G (2011) Molecular mechanisms of lymphangiogenesis in development and cancer. Int J Dev Biol 55(4-5):483-494. doi:10.1387/ijdb.103226ia

2. Alitalo K (2011) The lymphatic vasculature in disease. Nat Med 17(11):1371-1380. doi:10.1038/nm.2545

3. Cueni LN, Detmar M (2006) New insights into the molecular control of the lymphatic vascular system and its role in disease. J Invest Dermatol 126(10):2167-2177. doi:10.1038/sj.jid. 5700464

4. Halin C, Detmar M (2008) Chapter 1. Inflammation, angiogenesis, and lymphangiogenesis. Methods Enzymol 445:1-25. doi:10.1016/S0076-6879(08)03001-2

5. Hirakawa S, Hong YK, Harvey N, Schacht V, Matsuda K, Libermann T, Detmar M (2003) Identification of vascular lineage-specific genes by transcriptional profiling of isolated blood vascular and lymphatic endothelial cells. Am J Pathol 162(2):575-586. doi:10.1016/S0002-9440(10)63851-5

6. Kriehuber E, Breiteneder-Geleff S, Groeger M, Soleiman A, Schoppmann SF, Stingl G, Kerjaschki D, Maurer D (2001) Isolation and characterization of dermal lymphatic and blood endothelial cells reveal stable and functionally specialized cell lineages. J Exp Med 194(6):797-808

7. Petrova TV, Makinen T, Makela TP, Saarela J, Virtanen I, Ferrell RE, Finegold DN, Kerjaschki D, Yla-Herttuala S, Alitalo K (2002) Lymphatic endothelial reprogramming of vascular endothelial cells by the Prox-1 homeobox transcription factor. EMBO J 21(17):4593-4599

8. Makinen T, Veikkola T, Mustjoki S, Karpanen T, Catimel B, Nice EC, Wise L, Mercer A, Kowalski H, Kerjaschki D, Stacker SA, Achen MG, Alitalo K (2001) Isolated lymphatic endothelial cells transduce growth, survival and migratory signals via the VEGF-C/D receptor VEGFR-3. EMBO J 20(17):4762-4773. doi:10.1093/emboj/20.17.4762

9. Tammela T, Alitalo K (2010) Lymphangiogenesis: molecular mechanisms and future promise. Cell 140(4):460-476. doi:10. 1016/j.cell.2010.01.045

10. Kaipainen A, Korhonen J, Mustonen T, van Hinsbergh VW, Fang GH, Dumont D, Breitman M, Alitalo K (1995) Expression of the fms-like tyrosine kinase 4 gene becomes restricted to 
lymphatic endothelium during development. Proc Natl Acad Sci USA 92(8):3566-3570

11. Partanen TA, Arola J, Saaristo A, Jussila L, Ora A, Miettinen M, Stacker SA, Achen MG, Alitalo K (2000) VEGF-C and VEGF$\mathrm{D}$ expression in neuroendocrine cells and their receptor, VEGFR-3, in fenestrated blood vessels in human tissues. FASEB J 14(13):2087-2096. doi:10.1096/fj.99-1049com

12. Wigle JT, Oliver G (1999) Prox1 function is required for the development of the murine lymphatic system. Cell 98(6):769-778

13. Hong YK, Foreman K, Shin JW, Hirakawa S, Curry CL, Sage DR, Libermann T, Dezube BJ, Fingeroth JD, Detmar M (2004) Lymphatic reprogramming of blood vascular endothelium by Kaposi sarcoma-associated herpesvirus. Nat Genet 36(7):683-685

14. Banerji S, Ni J, Wang SX, Clasper S, Su J, Tammi R, Jones M, Jackson DG (1999) LYVE-1, a new homologue of the CD44 glycoprotein, is a lymph-specific receptor for hyaluronan. J Cell Biol 144(4):789-801

15. Gale NW, Prevo R, Espinosa J, Ferguson DJ, Dominguez MG, Yancopoulos GD, Thurston G, Jackson DG (2007) Normal lymphatic development and function in mice deficient for the lymphatic hyaluronan receptor LYVE-1. Mol Cell Biol 27(2):595-604. doi:10.1128/MCB.01503-06

16. Makinen T, Adams RH, Bailey J, Lu Q, Ziemiecki A, Alitalo K, Klein R, Wilkinson GA (2005) PDZ interaction site in ephrinB2 is required for the remodeling of lymphatic vasculature. Genes Dev 19(3):397-410. doi:10.1101/gad.330105

17. Mouta Carreira C, Nasser SM, di Tomaso E, Padera TP, Boucher Y, Tomarev SI, Jain RK (2001) LYVE-1 is not restricted to the lymph vessels: expression in normal liver blood sinusoids and down-regulation in human liver cancer and cirrhosis. Cancer Res 61(22):8079-8084

18. Breiteneder-Geleff S, Soleiman A, Kowalski H, Horvat R, Amann G, Kriehuber E, Diem K, Weninger W, Tschachler E, Alitalo K, Kerjaschki D (1999) Angiosarcomas express mixed endothelial phenotypes of blood and lymphatic capillaries: podoplanin as a specific marker for lymphatic endothelium. Am J Pathol 154(2):385-394. doi:10.1016/S0002-9440(10)65285-6

19. Schacht V, Ramirez MI, Hong YK, Hirakawa S, Feng D, Harvey N, Williams M, Dvorak AM, Dvorak HF, Oliver G, Detmar M (2003) T1alpha/podoplanin deficiency disrupts normal lymphatic vasculature formation and causes lymphedema. EMBO J 22(14):3546-3556. doi:10.1093/emboj/cdg342

20. Wick N, Haluza D, Gurnhofer E, Raab I, Kasimir MT, Prinz M, Steiner CW, Reinisch C, Howorka A, Giovanoli P, Buchsbaum S, Krieger S, Tschachler E, Petzelbauer P, Kerjaschki D (2008) Lymphatic precollectors contain a novel, specialized subpopulation of podoplanin low, CCL27-expressing lymphatic endothelial cells. Am J Pathol 173(4):1202-1209. doi:10.2353/ ajpath.2008.080101

21. Hamrah P, Chen L, Zhang Q, Dana MR (2003) Novel expression of vascular endothelial growth factor receptor (VEGFR)-3 and VEGF-C on corneal dendritic cells. Am J Pathol 163(1):57-68. doi:10.1016/S0002-9440(10)63630-9

22. Cursiefen C, Chen L, Saint-Geniez M, Hamrah P, Jin Y, Rashid S, Pytowski B, Persaud K, Wu Y, Streilein JW, Dana R (2006) Nonvascular VEGF receptor 3 expression by corneal epithelium maintains avascularity and vision. Proc Natl Acad Sci U S A 103(30):11405-11410. doi:10.1073/pnas.0506112103

23. Burke Z, Oliver G (2002) Prox 1 is an early specific marker for the developing liver and pancreas in the mammalian foregut endoderm. Mech Dev 118(1-2):147-155

24. Lavado A, Oliver G (2007) Prox1 expression patterns in the developing and adult murine brain. Dev Dyn 236(2):518-524. doi:10.1002/dvdy.21024

25. Galeeva A, Treuter E, Tomarev S, Pelto-Huikko M (2007) A prospero-related homeobox gene Prox-1 is expressed during postnatal brain development as well as in the adult rodent brain. Neuroscience 146(2):604-616. doi:10.1016/j.neuroscience.2007. 02.002

26. Chen L, Cursiefen C, Barabino S, Zhang Q, Dana MR (2005) Novel expression and characterization of lymphatic vessel endothelial hyaluronate receptor 1 (LYVE-1) by conjunctival cells. Invest Ophthalmol Vis Sci 46(12):4536-4540. doi:10. 1167/iovs.05-0975

27. Cho CH, Koh YJ, Han J, Sung HK, Jong Lee H, Morisada T, Schwendener RA, Brekken RA, Kang G, Oike Y, Choi TS, Suda T, Yoo OJ, Koh GY (2007) Angiogenic role of LYVE-1-positive macrophages in adipose tissue. Circ Res 100(4):e47-e57. doi:10.1161/01.RES.0000259564.92792.93

28. Schledzewski K, Falkowski M, Moldenhauer G, Metharom P, Kzhyshkowska J, Ganss R, Demory A, Falkowska-Hansen B, Kurzen H, Ugurel S, Geginat G, Arnold B, Goerdt S (2006) Lymphatic endothelium-specific hyaluronan receptor LYVE-1 is expressed by stabilin- $1+, \mathrm{F} 4 / 80+, \mathrm{CD} 11 \mathrm{~b}+$ macrophages in malignant tumours and wound healing tissue in vivo and in bone marrow cultures in vitro: implications for the assessment of lymphangiogenesis. J Pathol 209(1):67-77. doi:10.1002/path. 1942

29. Williams MC, Cao Y, Hinds A, Rishi AK, Wetterwald A (1996) $\mathrm{T} 1$ alpha protein is developmentally regulated and expressed by alveolar type I cells, choroid plexus, and ciliary epithelia of adult rats. Am J Respir Cell Mol Biol 14(6):577-585. doi:10. 1165/ajrcmb.14.6.8652186

30. Kaji C, Tomooka M, Kato Y, Kojima H, Sawa Y (2012) The expression of podoplanin and classic cadherins in the mouse brain. J Anat 220(5):435-446. doi:10.1111/j.1469-7580.2012. 01484.X

31. Ramirez MI, Millien G, Hinds A, Cao Y, Seldin DC, Williams MC (2003) T1alpha, a lung type I cell differentiation gene, is required for normal lung cell proliferation and alveolus formation at birth. Dev Biol 256(1):61-72

32. Bekiaris V, Withers D, Glanville SH, McConnell FM, Parnell SM, Kim MY, Gaspal FM, Jenkinson E, Sweet C, Anderson G, Lane PJ (2007) Role of CD30 in B/T segregation in the spleen. J Immunol 179(11):7535-7543

33. Malhotra D, Fletcher AL, Astarita J, Lukacs-Kornek V, Tayalia P, Gonzalez SF, Elpek KG, Chang SK, Knoblich K, Hemler ME, Brenner MB, Carroll MC, Mooney DJ, Turley SJ (2012) Transcriptional profiling of stroma from inflamed and resting lymph nodes defines immunological hallmarks. Nat Immunol 13(5):499-510. doi:10.1038/ni.2262

34. Hou TZ, Bystrom J, Sherlock JP, Qureshi O, Parnell SM, Anderson G, Gilroy DW, Buckley CD (2010) A distinct subset of podoplanin (gp38) expressing $\mathrm{F} 4 / 80+$ macrophages mediate phagocytosis and are induced following zymosan peritonitis. FEBS Lett 584(18):3955-3961. doi:10.1016/j.febslet.2010.07. 053

35. Kerrigan AM, Navarro-Nunez L, Pyz E, Finney BA, Willment JA, Watson SP, Brown GD (2012) Podoplanin-expressing inflammatory macrophages activate murine platelets via CLEC2. J Thromb Haemost 10(3):484-486. doi:10.1111/j.1538-7836. 2011.04614.x

36. Peters A, Pitcher LA, Sullivan JM, Mitsdoerffer M, Acton SE, Franz B, Wucherpfennig K, Turley S, Carroll MC, Sobel RA, Bettelli E, Kuchroo VK (2011) Th17 cells induce ectopic lymphoid follicles in central nervous system tissue inflammation. Immunity 35(6):986-996. doi:10.1016/j.immuni.2011.10.015

37. Fujii T, Zen Y, Sato Y, Sasaki M, Enomae M, Minato H, Masuda S, Uehara T, Katsuyama T, Nakanuma Y (2008) Podoplanin is a useful diagnostic marker for epithelioid hemangioendothelioma of the liver. Mod Pathol 21(2):125-130. doi:10.1038/modpathol. 3800986 
38. Baluk P, McDonald DM (2008) Markers for microscopic imaging of lymphangiogenesis and angiogenesis. Ann N Y Acad Sci 1131:1-12. doi:10.1196/annals.1413.001

39. Clasper S, Royston D, Baban D, Cao Y, Ewers S, Butz S, Vestweber D, Jackson DG (2008) A novel gene expression profile in lymphatics associated with tumor growth and nodal metastasis. Cancer Res 68(18):7293-7303. doi:10.1158/00085472.CAN-07-6506

40. Groger M, Loewe R, Holnthoner W, Embacher R, Pillinger M, Herron GS, Wolff K, Petzelbauer P (2004) IL-3 induces expression of lymphatic markers Prox-1 and podoplanin in human endothelial cells. J Immunol 173(12):7161-7169

41. Baluk P, Tammela T, Ator E, Lyubynska N, Achen MG, Hicklin DJ, Jeltsch M, Petrova TV, Pytowski B, Stacker SA, Yla-Herttuala S, Jackson DG, Alitalo K, McDonald DM (2005) Pathogenesis of persistent lymphatic vessel hyperplasia in chronic airway inflammation. J Clin Invest 115(2):247-257. doi:10. 1172/JCI22037

42. Johnson LA, Prevo R, Clasper S, Jackson DG (2007) Inflammation-induced uptake and degradation of the lymphatic endothelial hyaluronan receptor LYVE-1. J Biol Chem 282(46): 33671-33680. doi:10.1074/jbc.M702889200

43. Vigl B, Aebischer D, Nitschke M, Iolyeva M, Rothlin T, Antsiferova O, Halin C (2011) Tissue inflammation modulates gene expression of lymphatic endothelial cells and dendritic cell migration in a stimulus-dependent manner. Blood 118(1): 205-215. doi:10.1182/blood-2010-12-326447

44. Huggenberger R, Siddiqui SS, Brander D, Ullmann S, Zimmermann K, Antsiferova M, Werner S, Alitalo K, Detmar M (2011) An important role of lymphatic vessel activation in limiting acute inflammation. Blood 117(17):4667-4678. doi:10. 1182/blood-2010-10-316356

45. Flister MJ, Wilber A, Hall KL, Iwata C, Miyazono K, Nisato RE, Pepper MS, Zawieja DC, Ran S (2010) Inflammation induces lymphangiogenesis through up-regulation of VEGFR-3 mediated by NF-kappaB and Prox1. Blood 115(2):418-429. doi:10.1182/blood-2008-12-196840

46. Proulx ST, Luciani P, Dieterich LC, Karaman S, Leroux JC, Detmar M (2013) Expansion of the lymphatic vasculature in cancer and inflammation: new opportunities for in vivo imaging and drug delivery. J Control Release. doi:10.1016/j.jconrel. 2013.04.027

47. Kunstfeld R, Hirakawa S, Hong YK, Schacht V, Lange-Asschenfeldt B, Velasco P, Lin C, Fiebiger E, Wei X, Wu Y, Hicklin D, Bohlen P, Detmar M (2004) Induction of cutaneous delayed-type hypersensitivity reactions in VEGF-A transgenic mice results in chronic skin inflammation associated with persistent lymphatic hyperplasia. Blood 104(4):1048-1057. doi:10. 1182/blood-2003-08-2964

48. Zhang Q, Lu Y, Proulx ST, Guo R, Yao Z, Schwarz EM, Boyce $\mathrm{BF}$, Xing L (2007) Increased lymphangiogenesis in joints of mice with inflammatory arthritis. Arthritis Res Ther 9(6):R118. doi: $10.1186 /$ ar2326

49. Xu H, Edwards J, Banerji S, Prevo R, Jackson DG, Athanasou NA (2003) Distribution of lymphatic vessels in normal and arthritic human synovial tissues. Ann Rheum Dis 62(12): $1227-1229$

50. Shi J, Liang Q, Wang Y, Mooney R, Boyce B, Xing L (2012) Use of a whole-slide imaging system to assess the presence and alteration of lymphatic vessels in joint sections of arthritic mice. Biotech Histochem. doi:10.3109/10520295.2012.729864

51. Shi VY, Bao L, Chan LS (2012) Inflammation-driven dermal lymphangiogenesis in atopic dermatitis is associated with $\mathrm{CD} 11 \mathrm{~b}+$ macrophage recruitment and VEGF-C up-regulation in the IL-4-transgenic mouse model. Microcirculation 19(7): 567-579. doi:10.1111/j.1549-8719.2012.00189.x
52. Alexander JS, Chaitanya GV, Grisham MB, Boktor M (2010) Emerging roles of lymphatics in inflammatory bowel disease. Ann N Y Acad Sci 1207(Suppl 1):E75-E85. doi:10.1111/j.17496632.2010.05757.x

53. Jurisic G, Sundberg JP, Bleich A, Leiter EH, Broman KW, Buechler G, Alley L, Vestweber D, Detmar M (2010) Quantitative lymphatic vessel trait analysis suggests Vcam1 as candidate modifier gene of inflammatory bowel disease. Genes Immun 11(3):219-231. doi:10.1038/gene.2010.4

54. Nagy JA, Vasile E, Feng D, Sundberg C, Brown LF, Detmar MJ, Lawitts JA, Benjamin L, Tan X, Manseau EJ, Dvorak AM, Dvorak HF (2002) Vascular permeability factor/vascular endothelial growth factor induces lymphangiogenesis as well as angiogenesis. J Exp Med 196(11):1497-1506

55. Mumprecht V, Roudnicky F, Detmar M (2012) Inflammationinduced lymph node lymphangiogenesis is reversible. Am J Pathol 180(3):874-879. doi:10.1016/j.ajpath.2011.11.010

56. Kelley PM, Conner AL, Tempero RM (2013) Lymphatic vessel memory stimulated by recurrent inflammation. Am J Pathol. doi:10.1016/j.ajpath.2013.02.025

57. Hirakawa S, Kodama S, Kunstfeld R, Kajiya K, Brown LF, Detmar M (2005) VEGF-A induces tumor and sentinel lymph node lymphangiogenesis and promotes lymphatic metastasis. J Exp Med 201(7):1089-1099. doi:10.1084/jem.20041896

58. Angeli V, Ginhoux F, Llodra J, Quemeneur L, Frenette PS, Skobe M, Jessberger R, Merad M, Randolph GJ (2006) B celldriven lymphangiogenesis in inflamed lymph nodes enhances dendritic cell mobilization. Immunity 24(2):203-215. doi:10. 1016/j.immuni.2006.01.003

59. Halin C, Tobler NE, Vigl B, Brown LF, Detmar M (2007) VEGF-A produced by chronically inflamed tissue induces lymphangiogenesis in draining lymph nodes. Blood 110(9):3158-3167. doi:10.1182/blood-2007-01-066811

60. Kataru RP, Jung K, Jang C, Yang H, Schwendener RA, Baik JE, Han SH, Alitalo K, Koh GY (2009) Critical role of CD11b+ macrophages and VEGF in inflammatory lymphangiogenesis, antigen clearance, and inflammation resolution. Blood 113(22):5650-5659. doi:10.1182/blood-2008-09-176776

61. Kataru RP, Kim H, Jang C, Choi DK, Koh BI, Kim M, Gollamudi S, Kim YK, Lee SH, Koh GY (2011) T lymphocytes negatively regulate lymph node lymphatic vessel formation. Immunity 34(1):96-107. doi:10.1016/j.immuni.2010.12.016

62. Hong YK, Lange-Asschenfeldt B, Velasco P, Hirakawa S, Kunstfeld R, Brown LF, Bohlen P, Senger DR, Detmar M (2004) VEGF-A promotes tissue repair-associated lymphatic vessel formation via VEGFR-2 and the alpha1beta1 and alpha2beta1 integrins. FASEB J 18(10):1111-1113

63. Huggenberger R, Ullmann S, Proulx ST, Pytowski B, Alitalo K, Detmar M (2010) Stimulation of lymphangiogenesis via VEGFR-3 inhibits chronic skin inflammation. J Exp Med 207(10):2255-2269. doi:10.1084/jem.20100559

64. Forsythe JA, Jiang BH, Iyer NV, Agani F, Leung SW, Koos RD, Semenza GL (1996) Activation of vascular endothelial growth factor gene transcription by hypoxia-inducible factor 1 . Mol Cell Biol 16(9):4604-4613

65. Gale NW, Thurston G, Hackett SF, Renard R, Wang Q, McClain J, Martin C, Witte C, Witte MH, Jackson D, Suri C, Campochiaro PA, Wiegand SJ, Yancopoulos GD (2002) Angiopoietin2 is required for postnatal angiogenesis and lymphatic patterning, and only the latter role is rescued by angiopoietin-1. Dev Cell 3(3):411-423

66. Morisada T, Oike Y, Yamada Y, Urano T, Akao M, Kubota Y, Maekawa H, Kimura Y, Ohmura M, Miyamoto T, Nozawa S, Koh GY, Alitalo K, Suda T (2005) Angiopoietin-1 promotes LYVE-1-positive lymphatic vessel formation. Blood 105(12):4649-4656. doi:10.1182/blood-2004-08-3382 
67. Chang LK, Garcia-Cardena G, Farnebo F, Fannon M, Chen EJ, Butterfield C, Moses MA, Mulligan RC, Folkman J, Kaipainen A (2004) Dose-dependent response of FGF-2 for lymphangiogenesis. Proc Natl Acad Sci U S A 101(32):11658-11663. doi:10. 1073/pnas.0404272101

68. Shin JW, Min M, Larrieu-Lahargue F, Canron X, Kunstfeld R, Nguyen L, Henderson JE, Bikfalvi A, Detmar M, Hong YK (2006) Prox1 promotes lineage-specific expression of fibroblast growth factor (FGF) receptor-3 in lymphatic endothelium: a role for FGF signaling in lymphangiogenesis. Mol Biol Cell 17(2):576-584. doi:10.1091/mbc.E05-04-0368

69. Kajiya K, Hirakawa S, Ma B, Drinnenberg I, Detmar M (2005) Hepatocyte growth factor promotes lymphatic vessel formation and function. EMBO J 24(16):2885-2895. doi:10.1038/sj.emboj. 7600763

70. Cao R, Bjorndahl MA, Religa P, Clasper S, Garvin S, Galter D, Meister B, Ikomi F, Tritsaris K, Dissing S, Ohhashi T, Jackson DG, Cao Y (2004) PDGF-BB induces intratumoral lymphangiogenesis and promotes lymphatic metastasis. Cancer Cell 6(4):333-345. doi:10.1016/j.ccr.2004.08.034

71. Bjorndahl M, Cao R, Nissen LJ, Clasper S, Johnson LA, Xue Y, Zhou Z, Jackson D, Hansen AJ, Cao Y (2005) Insulin-like growth factors 1 and 2 induce lymphangiogenesis in vivo. Proc Natl Acad Sci U S A 102(43):15593-15598. doi:10.1073/pnas. 0507865102

72. Kang S, Lee SP, Kim KE, Kim HZ, Memet S, Koh GY (2009) Toll-like receptor 4 in lymphatic endothelial cells contributes to LPS-induced lymphangiogenesis by chemotactic recruitment of macrophages. Blood 113(11):2605-2613. doi:10.1182/blood2008-07-166934

73. Kim KE, Koh YJ, Jeon BH, Jang C, Han J, Kataru RP, Schwendener RA, Kim JM, Koh GY (2009) Role of CD11b+ macrophages in intraperitoneal lipopolysaccharide-induced aberrant lymphangiogenesis and lymphatic function in the diaphragm. Am J Pathol 175(4):1733-1745. doi:10.2353/ajpath.2009.090133

74. Baluk P, Hogmalm A, Bry M, Alitalo K, Bry K, McDonald DM (2013) Transgenic overexpression of interleukin-1beta induces persistent lymphangiogenesis but not angiogenesis in mouse airways. Am J Pathol 182(4):1434-1447. doi:10.1016/j.ajpath. 2012.12.003

75. Watari K, Nakao S, Fotovati A, Basaki Y, Hosoi F, Bereczky B, Higuchi R, Miyamoto T, Kuwano M, Ono M (2008) Role of macrophages in inflammatory lymphangiogenesis: enhanced production of vascular endothelial growth factor $\mathrm{C}$ and D through NF-kappaB activation. Biochem Biophys Res Commun 377(3):826-831. doi:10.1016/j.bbrc.2008.10.077

76. Kubota Y, Takubo K, Shimizu T, Ohno H, Kishi K, Shibuya M, Saya H, Suda T (2009) M-CSF inhibition selectively targets pathological angiogenesis and lymphangiogenesis. J Exp Med 206(5):1089-1102. doi:10.1084/jem.20081605

77. Cha HS, Bae EK, Koh JH, Chai JY, Jeon CH, Ahn KS, Kim J, Koh EM (2007) Tumor necrosis factor-alpha induces vascular endothelial growth factor-C expression in rheumatoid synoviocytes. J Rheumatol 34(1):16-19

78. Chaitanya GV, Franks SE, Cromer W, Wells SR, Bienkowska M, Jennings MH, Ruddell A, Ando T, Wang Y, Gu Y, Sapp M, Mathis JM, Jordan PA, Minagar A, Alexander JS (2010) Differential cytokine responses in human and mouse lymphatic endothelial cells to cytokines in vitro. Lymphat Res Biol 8(3):155-164. doi:10.1089/lrb 2010.0004

79. Kajiya K, Hirakawa S, Detmar M (2006) Vascular endothelial growth factor-A mediates ultraviolet B-induced impairment of lymphatic vessel function. Am J Pathol 169(4):1496-1503. doi:10.2353/ajpath.2006.060197

80. Zhou Q, Wood R, Schwarz EM, Wang YJ, Xing L (2010) Nearinfrared lymphatic imaging demonstrates the dynamics of lymph flow and lymphangiogenesis during the acute versus chronic phases of arthritis in mice. Arthritis Rheum 62(7):1881-1889. doi:10.1002/art.27464

81. Zhou Q, Guo R, Wood R, Boyce BF, Liang Q, Wang YJ, Schwarz EM, Xing L (2011) Vascular endothelial growth factor $\mathrm{C}$ attenuates joint damage in chronic inflammatory arthritis by accelerating local lymphatic drainage in mice. Arthritis Rheum 63(8):2318-2328. doi:10.1002/art.30421

82. Guo R, Zhou Q, Proulx ST, Wood R, Ji RC, Ritchlin CT, Pytowski B, Zhu Z, Wang YJ, Schwarz EM, Xing L (2009) Inhibition of lymphangiogenesis and lymphatic drainage via vascular endothelial growth factor receptor 3 blockade increases the severity of inflammation in a mouse model of chronic inflammatory arthritis. Arthritis Rheum 60(9):2666-2676. doi:10.1002/art.24764

83. Xia YP, Li B, Hylton D, Detmar M, Yancopoulos GD, Rudge JS (2003) Transgenic delivery of VEGF to mouse skin leads to an inflammatory condition resembling human psoriasis. Blood 102(1):161-168. doi:10.1182/blood-2002-12-3793

84. Hirakawa S, Fujii S, Kajiya K, Yano K, Detmar M (2005) Vascular endothelial growth factor promotes sensitivity to ultraviolet B-induced cutaneous photodamage. Blood 105(6): 2392-2399. doi:10.1182/blood-2004-06-2435

85. Kajiya K, Sawane M, Huggenberger R, Detmar M (2009) Activation of the VEGFR-3 pathway by VEGF-C attenuates UVBinduced edema formation and skin inflammation by promoting lymphangiogenesis. J Invest Dermatol 129(5):1292-1298. doi:10. 1038/jid.2008.351

86. Kajiya K, Detmar M (2006) An important role of lymphatic vessels in the control of UVB-induced edema formation and inflammation. J Invest Dermatol 126(4):919-921. doi:10.1038/ sj.jid.5700126

87. Jurisic G, Sundberg JP, Detmar M (2013) Blockade of VEGF receptor-3 aggravates inflammatory bowel disease and lymphatic vessel enlargement. Inflamm Bowel Dis 19:1983-1989

88. Tewalt EF, Cohen JN, Rouhani SJ, Engelhard VH (2012) Lymphatic endothelial cells-key players in regulation of tolerance and immunity. Front Immunol 3:305. doi:10.3389/fimmu.2012. 00305

89. McKimmie CS, Singh MD, Hewit K, Lopez-Franco O, Le Brocq M, Rose-John S, Lee KM, Baker AH, Wheat R, Blackbourn DJ, Nibbs RJ, Graham GJ (2013) An analysis of the function and expression of D6 on lymphatic endothelial cells. Blood. doi:10. 1182/blood-2012-04-425314

90. Vetrano S, Borroni EM, Sarukhan A, Savino B, Bonecchi R, Correale C, Arena V, Fantini M, Roncalli M, Malesci A, Mantovani A, Locati M, Danese S (2010) The lymphatic system controls intestinal inflammation and inflammation-associated colon cancer through the chemokine decoy receptor D6. Gut 59(2):197-206. doi:10.1136/gut.2009.183772

91. Cyster JG, Schwab SR (2012) Sphingosine-1-phosphate and lymphocyte egress from lymphoid organs. Annu Rev Immunol 30:69-94. doi:10.1146/annurev-immunol-020711-075011

92. Tan KW, Yeo KP, Wong FH, Lim HY, Khoo KL, Abastado JP, Angeli V (2012) Expansion of cortical and medullary sinuses restrains lymph node hypertrophy during prolonged inflammation. J Immunol 188(8):4065-4080. doi:10.4049/jimmunol. 1101854

93. Khan O, Headley M, Gerard A, Wei W, Liu L, Krummel MF (2011) Regulation of T cell priming by lymphoid stroma. PLoS ONE 6(11):e26138. doi:10.1371/journal.pone.0026138

94. Lukacs-Kornek V, Malhotra D, Fletcher AL, Acton SE, Elpek KG, Tayalia P, Collier AR, Turley SJ (2011) Regulated release of nitric oxide by nonhematopoietic stroma controls expansion of the activated $\mathrm{T}$ cell pool in lymph nodes. Nat Immunol 12(11):1096-1104. doi:10.1038/ni.2112 
95. Podgrabinska S, Kamalu O, Mayer L, Shimaoka M, Snoeck H, Randolph GJ, Skobe M (2009) Inflamed lymphatic endothelium suppresses dendritic cell maturation and function via Mac-1/ ICAM-1-dependent mechanism. J Immunol 183(3):1767-1779. doi:10.4049/jimmunol.0802167

96. Cohen JN, Guidi CJ, Tewalt EF, Qiao H, Rouhani SJ, Ruddell A, Farr AG, Tung KS, Engelhard VH (2010) Lymph node-resident lymphatic endothelial cells mediate peripheral tolerance via Aire-independent direct antigen presentation. J Exp Med 207(4):681-688. doi:10.1084/jem.20092465

97. Fletcher AL, Lukacs-Kornek V, Reynoso ED, Pinner SE, Bellemare-Pelletier A, Curry MS, Collier AR, Boyd RL, Turley SJ (2010) Lymph node fibroblastic reticular cells directly present peripheral tissue antigen under steady-state and inflammatory conditions. J Exp Med 207(4):689-697. doi:10.1084/jem. 20092642

98. Tewalt EF, Cohen JN, Rouhani SJ, Guidi CJ, Qiao H, Fahl SP, Conaway MR, Bender TP, Tung KS, Vella AT, Adler AJ, Chen L, Engelhard VH (2012) Lymphatic endothelial cells induce tolerance via PD-L1 and lack of costimulation leading to highlevel PD-1 expression on CD8 T cells. Blood 120(24): 4772-4782. doi:10.1182/blood-2012-04-427013

99. Alitalo A, Detmar M (2012) Interaction of tumor cells and lymphatic vessels in cancer progression. Oncogene 31(42): 4499-4508. doi:10.1038/onc.2011.602

100. Shimizu Y, Shibata R, Shintani S, Ishii M, Murohara T (2012) Therapeutic lymphangiogenesis with implantation of adiposederived regenerative cells. J Am Heart Assoc 1(4):e000877. doi:10.1161/JAHA.112.000877

101. Choi I, Lee YS, Chung HK, Choi D, Ecoiffier T, Lee HN, Kim KE, Lee S, Park EK, Maeng YS, Kim NY, Ladner RD, Petasis NA, Koh CJ, Chen L, Lenz HJ, Hong YK (2013) Interleukin-8 reduces post-surgical lymphedema formation by promoting lymphatic vessel regeneration. Angiogenesis 16(1):29-44. doi:10.1007/s10456-012-9297-6

102. Choi I, Lee S, Kyoung Chung H, Suk Lee Y, Eui Kim K, Choi D, Park EK, Yang D, Ecoiffier T, Monahan J, Chen W, Aguilar B, Lee HN, Yoo J, Koh CJ, Chen L, Wong AK, Hong YK (2012) 9-cis retinoic acid promotes lymphangiogenesis and enhances lymphatic vessel regeneration: therapeutic implications of 9-cis retinoic acid for secondary lymphedema. Circulation 125(7):872-882. doi:10.1161/CIRCULATIONAHA.111. 030296

103. Marino D, Dabouras V, Brändli AW, Detmar M (2011) A role for all-trans-retinoic acid in the early steps of lymphatic vasculature development. J Vasc Res 48:236-251

104. Iwata C, Kano MR, Komuro A, Oka M, Kiyono K, Johansson E, Morishita Y, Yashiro M, Hirakawa K, Kaminishi M, Miyazono K (2007) Inhibition of cyclooxygenase-2 suppresses lymph node metastasis via reduction of lymphangiogenesis. Cancer Res 67(21):10181-10189. doi:10.1158/0008-5472.CAN-07-2366

105. Kashiwagi S, Hosono K, Suzuki T, Takeda A, Uchinuma E, Majima M (2011) Role of COX-2 in lymphangiogenesis and restoration of lymphatic flow in secondary lymphedema. Lab Invest 91(9):1314-1325. doi:10.1038/labinvest.2011.84

106. Karnezis T, Shayan R, Caesar C, Roufail S, Harris NC, Ardipradja K, Zhang YF, Williams SP, Farnsworth RH, Chai MG, Rupasinghe TW, Tull DL, Baldwin ME, Sloan EK, Fox SB, Achen MG, Stacker SA (2012) VEGF-D promotes tumor metastasis by regulating prostaglandins produced by the collecting lymphatic endothelium. Cancer Cell 21(2):181-195. doi:10.1016/j.ccr.2011.12.026

107. Yao LC, Baluk P, Feng J, McDonald DM (2010) Steroidresistant lymphatic remodeling in chronically inflamed mouse airways. Am J Pathol 176(3):1525-1541. doi:10.2353/ajpath. 2010.090909
108. Steele MM, Kelley PM, Schieler AM, Tempero RM (2011) Glucocorticoids suppress corneal lymphangiogenesis. Cornea 30(12):1442-1447. doi:10.1097/ICO.0b013e318213f39f

109. Hos D, Saban DR, Bock F, Regenfuss B, Onderka J, Masli S, Cursiefen C (2011) Suppression of inflammatory corneal lymphangiogenesis by application of topical corticosteroids. Arch Ophthalmol 129(4):445-452. doi:10.1001/archophthalmol.2011. 42

110. Yano A, Fujii Y, Iwai A, Kawakami S, Kageyama Y, Kihara K (2006) Glucocorticoids suppress tumor lymphangiogenesis of prostate cancer cells. Clin Cancer Res 12(20 Pt 1):6012-6017. doi:10.1158/1078-0432.CCR-06-0749

111. Okanobo A, Chauhan SK, Dastjerdi MH, Kodati S, Dana R (2012) Efficacy of topical blockade of interleukin-1 in experimental dry eye disease. Am J Ophthalmol 154(1):63-71. doi:10. 1016/j.ajo.2012.01.034

112. Shinriki S, Jono H, Ueda M, Ota K, Ota T, Sueyoshi T, Oike Y, Ibusuki M, Hiraki A, Nakayama H, Shinohara M, Ando Y (2011) Interleukin-6 signalling regulates vascular endothelial growth factor-C synthesis and lymphangiogenesis in human oral squamous cell carcinoma. J Pathol 225(1):142-150. doi:10.1002/path.2935

113. Polzer K, Baeten D, Soleiman A, Distler J, Gerlag DM, Tak PP, Schett G, Zwerina J (2008) Tumour necrosis factor blockade increases lymphangiogenesis in murine and human arthritic joints. Ann Rheum Dis 67(11):1610-1616. doi:10.1136/ard. 2007.083394

114. Schulz MM, Reisen F, Zgraggen S, Fischer S, Yuen D, Kang GJ, Chen L, Schneider G, Detmar M (2012) Phenotype-based highcontent chemical library screening identifies statins as inhibitors of in vivo lymphangiogenesis. Proc Natl Acad Sci U S A 109(40):E2665-E2674. doi:10.1073/pnas.1206036109

115. Baluk P, Yao LC, Feng J, Romano T, Jung SS, Schreiter JL, Yan L, Shealy DJ, McDonald DM (2009) TNF-alpha drives remodeling of blood vessels and lymphatics in sustained airway inflammation in mice. J Clin Invest 119(10):2954-2964. doi:10. 1172/JCI37626

116. Fiorentini S, Luganini A, Dell'Oste V, Lorusso B, Cervi E, Caccuri F, Bonardelli S, Landolfo S, Caruso A, Gribaudo G (2011) Human cytomegalovirus productively infects lymphatic endothelial cells and induces a secretome that promotes angiogenesis and lymphangiogenesis through interleukin-6 and granulocyte-macrophage colony-stimulating factor. J Gen Virol 92(Pt 3):650-660. doi:10.1099/vir.0.025395-0

117. Chen X, Xie Q, Cheng X, Diao X, Cheng Y, Liu J, Xie W, Chen Z, Zhu B (2010) Role of interleukin-17 in lymphangiogenesis in non-small-cell lung cancer: enhanced production of vascular endothelial growth factor $\mathrm{C}$ in non-small-cell lung carcinoma cells. Cancer Sci 101(11):2384-2390. doi:10.1111/j.1349-7006. 2010.01684.x

118. Chauhan SK, Jin Y, Goyal S, Lee HS, Fuchsluger TA, Lee HK, Dana R (2011) A novel pro-lymphangiogenic function for Th17/IL17. Blood 118(17):4630-4634. doi:10.1182/blood-2011-01-332049

119. Yamashita M, Iwama N, Date F, Shibata N, Miki H, Yamauchi K, Sawai T, Sato S, Takahashi T, Ono M (2009) Macrophages participate in lymphangiogenesis in idiopathic diffuse alveolar damage through CCL19-CCR7 signal. Hum Pathol 40(11):1553-1563. doi:10.1016/j.humpath.2009.03.021

120. Zhuo W, Jia L, Song N, Lu XA, Ding Y, Wang X, Song X, Fu Y, Luo Y (2012) The CXCL12-CXCR4 chemokine pathway: a novel axis regulates lymphangiogenesis. Clin Cancer Res 18(19):5387-5398. doi:10.1158/1078-0432.CCR-12-0708

121. Su JL, Shih JY, Yen ML, Jeng YM, Chang CC, Hsieh CY, Wei LH, Yang PC, Kuo ML (2004) Cyclooxygenase-2 induces EP1and HER-2/Neu-dependent vascular endothelial growth factor-C up-regulation: a novel mechanism of lymphangiogenesis in lung adenocarcinoma. Cancer Res 64(2):554-564 
122. Hosono K, Suzuki T, Tamaki H, Sakagami H, Hayashi I, Narumiya S, Alitalo K, Majima M (2011) Roles of prostaglandin E2-EP3/EP4 receptor signaling in the enhancement of lymphangiogenesis during fibroblast growth factor-2-induced granulation formation. Arterioscler Thromb Vasc Biol 31(5): 1049-1058. doi:10.1161/ATVBAHA.110.222356

123. Kajiya K, Huggenberger R, Drinnenberg I, Ma B, Detmar M (2008) Nitric oxide mediates lymphatic vessel activation via soluble guanylate cyclase alpha1beta1-impact on inflammation. FASEB J 22(2):530-537. doi:10.1096/fj.07-8873com

124. Lahdenranta J, Hagendoorn J, Padera TP, Hoshida T, Nelson G, Kashiwagi S, Jain RK, Fukumura D (2009) Endothelial nitric oxide synthase mediates lymphangiogenesis and lymphatic metastasis. Cancer Res 69(7):2801-2808. doi:10.1158/00085472.CAN-08-4051 